\title{
Sciatic hernia clinically mimicking obturator hernia, missed by ultrasonography: case report
}

\author{
Ultrasonografi tarafindan atlanan ve klinik olarak obturator herniyi taklit eden \\ siyatik herni: Olgu sunumu
}

\author{
Shiraz Ahmad RATHER, Tanveer Iqbal DAR, Aijaz Ahmad MALIK, \\ Fazal Q PARRAY, Mukhtar AHMAD, Syed ASRAR
}

\begin{abstract}
Sciatic hernia is a rare pelvic floor hernia that occurs through the greater or lesser sciatic foramen. Sciatic hernias often present as pelvic pain, particularly in women, and diagnosis can be difficult. Sciatic hernia is one of the rarest forms of internal hernia, which can present as signs and symptoms of small bowel obstruction, swelling in the respective gluteal region or pelvic pain. Transabdominal and transgluteal operative approaches, including laparoscopic repair, have been reported. We present a case of left-sided sciatic hernia with incarcerated small bowel as its contents. The hernia was missed by ultrasonography and plain abdominal radiography, but the clinical features were suggestive of an obturator hernia.
\end{abstract}

Key Words: Sciatic hernia; obturator hernia; intestinal obstruction.

An incarcerated sciatic hernia requires immediate surgery, as the incidence of strangulation and bowel gangrene is high, even if symptom duration prior to patient presentation is short, ${ }^{[1-4]}$ unlike other causes of small bowel obstruction (SBO) such as adhesions, in which conservative treatment and expectant observation may be appropriate. ${ }^{[5]}$ Sciatic hernias are of three types. Type 1 (supra piriform muscle) is the most common (60\%), followed by sub-piriform, type $2(30 \%)$, while type 3 (subspinous, through the lesser sciatic foramen) is the least common. ${ }^{[6]}$ Various imaging mo-
Siyatik herni, büyük veya küçük siyatik foramen içinden geçerek oluşan nadir bir pelvis tabanı hernisidir. Siyatik herniler, özellikle kadınlarda sıklıkla pelvik ağrı şeklinde belirti verir ve tanısı güç olabilir. Siyatik herni, ince bağırsak tıkanıklığının belirti ve semptomları olan ilgili taraftaki gluteal bölgede şişlik veya pelvik ağrı şeklinde belirti verebilen en nadir internal herni formlarından birisidir. Laparoskopik onarımı da içeren transabdominal ve transgluteal operatif yaklaşımlar rapor edilmiştir. Biz, içeriği şeklinde de hapsolmuş ince bağırsakla birlikte olan bir sol taraflı siyatik herni olgusunu sunuyoruz. Herni, ultrasonografi ve düz abdominal grafi tarafından atlanmış ve obturator herniyi düşündürmüştür.

Anahtar Sözcükler: Siyatik herni; obturator herni; bağırsak tıkanıklığı.

dalities have been applied in diagnosing this disorder. ${ }^{[5]}$ A careful physical examination of the buttocks may reveal a tender or non-tender gluteal mass. ${ }^{[5]}$ Only 53 cases of sciatic hernia have been reported to date.

The aim of reporting this rare case is to highlight the clinical and ultrasonographic inability to diagnose sciatic hernia, and to stress that exact diagnosis is dependent on laparotomy in most such cases presenting to the emergency department, especially when the role of other investigations like computerized tomography (CT) scan is ruled out due to patient instability. Srinagar, Hindistan. 


\section{CASE REPORT}

An 80-year-old thin, multiparous female presented to the accident and emergency department of our tertiary care institute with complaints of lower abdominal pain, constipation, recurrent vomiting, and abdominal distention for the last two days. Her history revealed recurrent abdominal colic episodes associated with vomiting, which were managed conservatively at the periphery. There was no history of abdominal surgery of any type. On examination, she was febrile and dehydrated with a pulse rate of 108 beats per minute. Her blood pressure (BP) was 100/60 mmHg. Her abdomen was distended with visible peristalsis from right to left and exaggerated bowel sounds on auscultation. Laboratory investigations revealed hemoglobin $(\mathrm{Hb})$ of $9 \mathrm{~g} / \mathrm{dl}$ and total leukocyte count of 14,500 with $90 \%$ neutrophils. Conray study revealed small intestinal obstruction with dilated gut proximally. Ultrasonography (USG) and plain X-ray of the abdomen revealed the same findings without localization of the site of obstruction. The patient was explored immediately in view of the dynamic obstruction with suspicion of obturator hernia because she was an elderly, lean, multiparous female, with history of recurrent bowel obstruction, and current diagnosis of SBO, all favoring obturator hernia. On laparotomy, a loop of small bowel was seen passing over the piriform muscle (type 1) through the greater sciatic foramen (Figs. 1 and 2). The bowel was reduced and viability ensured (Fig. 3). The sciatic foramen was covered by a patch of endopelvic fascia, and the patient was discharged on the 7th postoperative day without no new complaint. She has been under follow-up in our outpatient department for the last seven months and is doing well.

\section{DISCUSSION}

Small bowel obstruction (SBO) is a commonly encountered problem in an emergency department. In a Mayo clinic series, of 289 patients and 314 op-

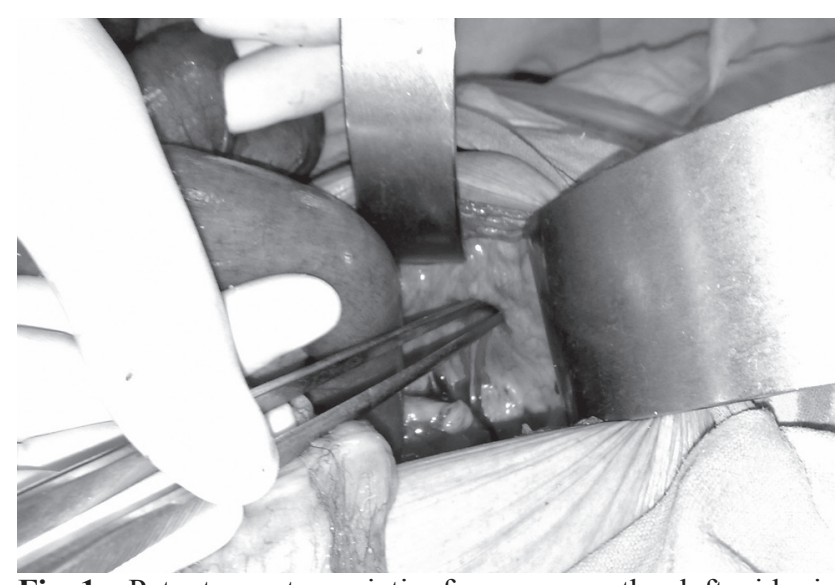

Fig. 1. Patent greater sciatic foramen on the left side is shown with the help of forceps, after an exploratory laparotomy was done. erations for SBO, adhesions (49\%) and neoplasms $(16.2 \%)$ were the most common causes. Hernias were the third most commonly encountered etiology, contributing to $15 \%$ of cases, but less than one-third of these were internal hernias related to entrapment of the small intestine in mesenteric defects. ${ }^{[1]}$ Only 53 cases of sciatic hernia have been documented, ${ }^{[5]}$ and due to a great variety of clinical presentations that depend on hernial content, this uncommon disease is difficult to diagnose. ${ }^{[2-4]}$ Hernia of the ureter or bladder into the sciatic foramen will manifest as urinary tract symptoms. Other contents like colon, omentum, fallopian tubes, ovary, and Meckel diverticulum have also been described. On rare occasions, sciatic hernias may mimic sciatica, with back pain or leg pain owing to compression of the sciatic nerve. ${ }^{[5]}$ It can present as a painless, reducible swelling in the gluteal region. ${ }^{[3]}$ Transabdominal approach is recommended in patients who present with SBO, especially when incarceration or strangulation is suspected. On the other hand, a less invasive transgluteal approach may be used when the herniated segments appear viable and reducible. ${ }^{[2-4]}$ Color Doppler demonstration of blood flow in bowel obstruction due to intussusception has been reported as a promising predictor of bowel viability and hydrostatic reducibility, and the absence of blood flow on Doppler scanning is highly suggestive of irreducibility and bowel ischemia. ${ }^{[5]}$ Plain abdominal radiography is diagnostic in about $50-60 \%$ of cases of SBO, equivocal in about $20-30 \%$ of cases and normal or misleading in $10-20 \%$ of cases, regardless of etiology. ${ }^{[5]}$ Nevertheless, identification of sciatic hernia on plain radiography is not easy. ${ }^{[2-4]}$ Barium studies of SBO are timeconsuming and the barium column may be diluted by intraluminal fluid obscuring the detail of obstruction. ${ }^{[5]}$ Sciatic hernia diagnosed by herniography has been reported but this method is invasive. ${ }^{[3]}$ Abdominal CT scan has been found useful in patients with features of SBO due to sciatic hernia, ${ }^{[2-4]}$ but a rational guideline

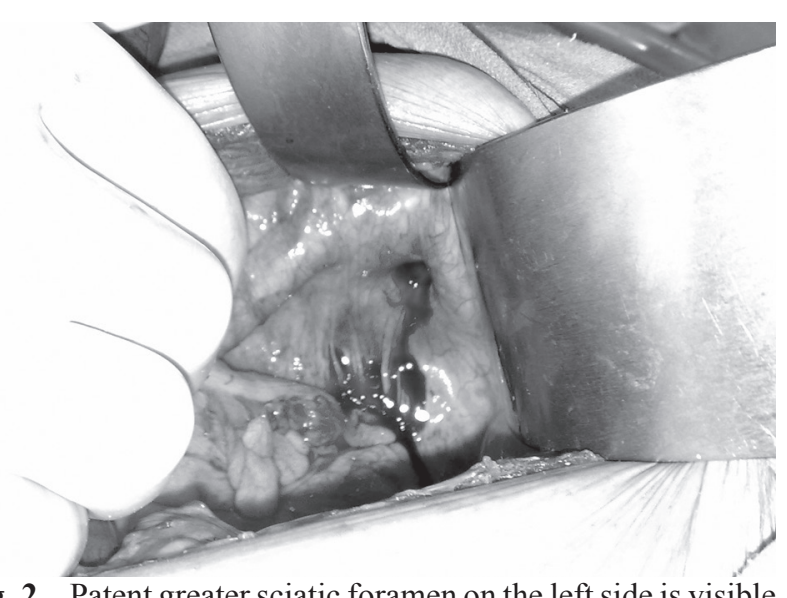

Fig. 2. Patent greater sciatic foramen on the left side is visible with blood oozing from it, after the incarcerated small bowel was reduced. 


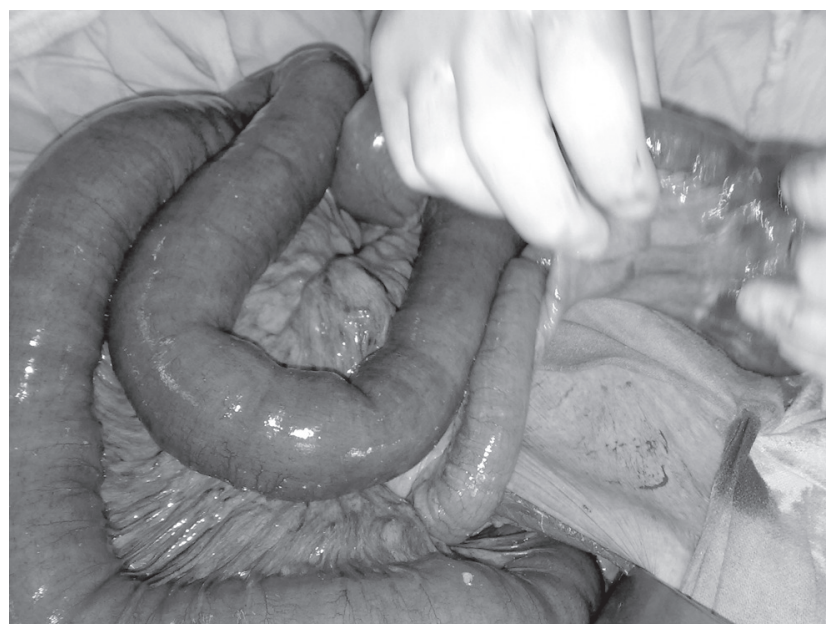

Fig. 3. Reduced small bowel with dilated proximal end with impending gangrene and narrowed distal end.

for its use in SBO has not been fully developed. Moreover, CT may not be a practical screening tool for all patients with non-specific abdominal pain or vomiting. ${ }^{[7,8]}$ USG is a versatile tool that can be performed at the bedside in the emergency department. Although abundant gas may prevent satisfactory examination of the abdomen, using fluid filled bowel loops as an acoustic window or performing a meticulous examination through the flank may show the presence, level and cause of SBO. However, less than $20 \%$ of underlying etiologies of SBO can definitively be recognized with this method. ${ }^{[5]}$ In our case, we could not do CT scan of the abdomen, and color Doppler was not considered because the patient was in full blown dynamic intestinal obstruction with features of impending small bowel gangrene, and was taken for emergency laparotomy. USG, however, was not helpful in delineating the cause of SBO. Laparoscopic transabdominal extra- peritoneal repair with plug and patch was performed by Bernard et al. ${ }^{[9]}$ in a case of sciatic hernia diagnosed before the laparoscopic procedure. The patient was an 80 -year-old female with a one-year history of chronic right lower limb pain not responding to the conventional analgesics.

In conclusion, SBO due to sciatic hernia is a rare entity without any medical treatment. With a high index of suspicion, an early laparotomy can save the patient from resection anastomosis and its complications.

\section{REFERENCES}

1. Mucha P Jr. Small intestinal obstruction. Surg Clin North Am 1987;67:597-620.

2. Ghahremani GG, Michael AS. Sciatic hernia with incarcerated ileum: CT and radiographic diagnosis. Gastrointest Radiol 1991;16:120-2.

3. Hayashi N, Suwa T, Kimura F, Okuno A, Ishizuka M, Kakizaki S, et al. Radiographic diagnosis and surgical repair of a sciatic hernia: report of a case. Surg Today 1995;25:1066-8.

4. Servant CT. An unusual cause of sciatica. A case report. Spine (Phila Pa 1976) 1998;23:2134-6.

5. Yu PC, Ko SF, Lee TY, Ng SH, Huang CC, Wan YL. Small bowel obstruction due to incarcerated sciatic hernia: ultrasound diagnosis. Br J Radiol 2002;75:381-3.

6. Javid PJ, Brooks DC. Hernias. In: Zinner MJ, Ashley SW, editors. Maingot's abdominal operations. 11th ed, McGraw Hill; 2007. p. 103-39.

7. Balthazar EJ. George W. Holmes Lecture. CT of small-bowel obstruction. AJR Am J Roentgenol 1994;162:255-61.

8. Tiao MM, Wan YL, Ng SH, Ko SF, Lee TY, Chen MC, et al. Sonographic features of small-bowel intussusception in pediatric patients. Acad Emerg Med 2001;8:368-73.

9. Bernard AC, Lee C, Hoskins J, Lee J, Patel S, Ginn G, et al. Sciatic hernia: laparoscopic transabdominal extraperitoneal repair with plug and patch. Hernia 2009; 1265-4906 (Print) 1248-9204. 